\title{
Pemenuhan Kewajiban Negara Terhadap Pekerja Terdampak Kebijakan Penanganan Covid-19 Di Kota Semarang ${ }^{1}$
}

\author{
Rahayu, Diastama Anggita Ramadhan, dan Pulung Widhi Hari Hananto \\ Fakultas Hukum Universitas Diponegoro Semarang Jawa Tengah Indonesia \\ Jln. Prof. Sudarto, SH, Tembalang - Semarang Jawa Tengah Indonesia 50275 \\ rahayu_undip@yahoo.com, diastamaanggita@lecturer.undip.ac.id, \\ pulungwidhiharihanan@lecturer.undip.ac.id
}

Received: 5 Maret 2021; Accepted: 12 Juni 2021; Published: 25 Agustus 2021

DOI: 10.20885/iustum.vol28.iss3.art8

\begin{abstract}
The employment sector is the most severely affected by the Covid-19 pandemic, including in Indonesia. More than 2 million people have lost their jobs, meaning they no longer have the income to make ends meet. This study aims to identify and analyze the impact of the Covid-19 pandemic on the employment status of workers in Semarang City, as well as the efforts made by the Semarang City Government to carry out its obligations to fulfill the rights of these workers. This research is a qualitative research with a doctrinal approach, and uses secondary data obtained through literature study in the form of regulatory and policy instruments as well as relevant scientific concepts. This study concludes that the Covid-19 pandemic has an impact on the employment status of some workers in the city of Semarang, namely experiencing termination of employment (PHK) or being 'sent home'. Regarding this situation, the Semarang City Government is trying its best so that the rights of workers affected by the Covid-19 handling policy can be fulfilled by the company by encouraging an agreement to be reached between the parties. For workers who are affected, the Semarang City Government also provides various stimuli and social assistance.
\end{abstract}

Key Word: Impact of the Covid-19 pandemic; protection of rights of the workers; semarang city

\section{Abstrak}

Sektor ketenagakerjaan merupakan sektor paling terdampak luar biasa oleh Pandemi Covid-19, termasuk di Indonesia. Lebih dari 2 juta orang harus kehilangan pekerjaannya, yang berarti mereka tidak lagi memiliki penghasilan untuk memenuhi kebutuhan hidupnya. Penelitian ini bertujuan untuk mengidentifikasi dan menganalisis dampak Pandemi Covid-19 terhadap status ketenagakerjaan para pekerja di Kota Semarang, serta upaya yang dilakukan oleh Pemerintah Kota Semarang melaksanakan kewajibannya memenuhi hak para pekerja tersebut. Penelitian ini merupakan penelitian kualitatif dengan pendekatan doktrinal, dan menggunakan data sekunder yang diperoleh melalui studi pustaka berupa perangkat regulasi dan kebijakan serta konsep-konsep keilmuan yang relevan. Penelitian ini menyimpulkan, bahwa Pandemi Covid-19 berdampak pada status ketenagakerjaan sebagian pekerja di Kota Semarang, yaitu mengalami pemutusan hubungan kerja (PHK) atau 'di rumahkan'. Terhadap situasi tersebut, Pemerintah Kota Semarang berusaha maksimal agar hak-hak pekerja yang terdampak kebijakan penanganan Covid-19 dapat dipenuhi oleh perusahaan dengan mendorong agar dicapai kesepakatan diantara para pihak. Bagi pekerja yang terdampak, Pemerintah Kota Semarang juga memberikan berbagai stimulus dan bantuan sosial.

Kata-kata Kunci: Perlindungan hak pekerja: dampak pandemi Covid-19, Kota Semarang

1 Penelitian ini Dibiayai dengan Sumber Dana Selain APBN DPA LPPM Universitas Diponegoro Tahun Anggaran 2020 dengan Judul "Membangun Model Perlindungan Hak Atas Pekerjaan yang Layak Bagi Pekerja Terdampak Pandemi Covid-19 di Provinsi Jawa Tengah” 


\section{Pendahuluan}

Pandemi Covid-19 yang mulai terdeteksi di Indonesia pada awal Maret 2020 berdampak negatif tidak hanya pada sektor kesehatan, namun juga berbagai sektor ekonomi. Pengurangan kegiatan ekonomi dan sosial yang dilakukan guna menghambat penyebaran Covid-19 di berbagai negara di dunia, termasuk Indonesia, berdampak pada kondisi sosial dan ekonomi masyarakat. Kebijakan Pemerintah untuk melakukan pembatasan sosial berskala besar (PSBB) berdampak pada aktivitas ekonomi masyarakat/dunia usaha yang secara langsung/tidak langsung juga berdampak pada sektor ketenagakerjaan. ${ }^{2}$

Laporan Badan Pusat Statistik (BPS) bulan April 2020 menyebutkan, bahwa pada triwulan pertama 2020 ekonomi Indonesia hanya tumbuh sebesar 2,97\%, turun jauh dibanding dengan periode yang sama 2019 yang mencapai angka 5,02\%.3 Bahkan pada kuartal kedua 2020 dilaporkan oleh BPS, bahwa pertumbuhan ekonomi Indonesia minus 5,32\%.4 Menurunnya kinerja ekonomi ini berdampak pada sektor ketenagakerjaan. Krisis ini mengakibatkan sejumlah tenaga kerja terpaksa 'di rumahkan' sementara waktu atau bahkan sebagian yang lainnya mengalami pemutusan hubungan kerja (PHK) oleh perusahaan tempat mereka bekerja. ${ }^{5}$

Berdasarkan data dari Kementerian Ketenagakerjaan, pada 7 April 2020 tercatat sebanyak 39.997 perusahaan di sektor formal yang memilih merumahkan dan melakukan PHK terhadap pekerjanya. 6 Jumlah pekerja terdampak Covid-19 ini semakin meningkat jumlahnya. Data BPS sampai dengan bulan November

2 Warwick McKibbin and Roshen Fernando, "The Macroeconomics Impact of Covid-19: Seven Scenarios”, Centre for Applied Macroeconomics Analysis, Working Paper, February 2020, hlm. 12.

${ }^{3}$ Badan Pusat Statistik Republik Indonesia. 2020. Ekonomi Indonesia Triwulan I 2020, Tumbuh 2,97 Persen. https://www.bps.go.id/pressrelease/2020/05/05/1736/ekonomi-indonesia-triwulan-i-2020-tumbuh-297-persen.html. Diakses pada Sabtu, 23 Mei 2020.

4 Jihad Akbar. 2020. Pertumbuhan Ekonomi RI Minus 5,32 Persen, Apa Dampaknya? https://www.kompas.com/tren/read/2020/08/05/151948365/pertumbuhan-ekonomi-ri-minus-532-persenapa-dampaknya?page=all\#: :text=KOMPAS.com $\% 20 \% 2 \mathrm{D} \% 20$ Pertumbuhan $\% 20$ ekonomi $\% 20$ Indonesia, hingga $\% 20$ minus $\% 204 \% 2$ C $8 \% 20$ persen. Diakses pada Sabtu, 10 Oktober 2020.

${ }^{5}$ Lihat analisis yang serupa, Mustakim dan Syafrida, S, "Pandemi Covid-19 Sebagai Alasan Force Majeure Dalam Melakukan Pemutusan Hubungan Kerja di Indonesia", sebagaimana dikutip kembali Khalda Fadilah, Andriyanto Adhi Nugroho, "Pemutusan Hubungan Kerja Pada Saat Pandemi Covid-19 Di Indonesia Ditinjau Dari Perspektif Hukum Ketenagakerjaan”, JUSTITIA: Jurnal Ilmu Hukum dan Humaniora, Vol. 8 No. 1 Tahun 2021: 334-349.

6 Ayomi Amindoni. 2020. Virus Corona: Gelombang PHK di tengah Pandemi Covid-19 diperkirakan mencapai puncak pada Bulan Juni, Kartu Prakerja Dianggap tak Efektif. https://www.bbc.com/indonesia/ indonesia-52218475. Diakses pada Sabtu, 23 Mei 2020. 
2020, terdapat 29,12 juta orang penduduk usia kerja yang terdampak Covid-19, meliputi: pengangguran karena Covid-19 sebesar 2,56 juta orang; tidak bekerja karena Covid-19 sebesar 1,77 juta orang, dan yang bekerja dengan mengalami pengurangan jam kerja sebanyak 24,03 juta orang. ${ }^{7}$

Di Provinsi Jawa Tengah, menurut data dari Dinas Tenaga Kerja dan Transmigrasi terdapat sekitar 148.791 orang pekerja yang terdampak Covid-19, dan 24.240 orang diantaranya terkena PHK. ${ }^{8}$ Empat wilayah di Provinsi Jawa Tengah dengan jumlah pekerja terdampak paling tinggi dapat dilihat pada tabel di bawah ini:

Tabel 1

Jumlah Pekerja Terdampak Kebijakan Penanganan Covid-19 di Provinsi Jawa Tengah

\begin{tabular}{lcc}
\hline \multicolumn{1}{c}{ Wilayah } & Pekerja di PHK & Pekerja di Rumahkan Sementara \\
\hline Kota Semarang & 7.142 Orang & 8.741 Orang \\
Kabupaten Cilacap & 426 Orang & 1.100 Orang \\
Kota Salatiga & 373 Orang & 1.014 Orang \\
Kota Tegal & 541 Orang & 525 Orang \\
\hline
\end{tabular}

Sumber: Diolah dari Data Dinas Tenaga Kerja dan Transmigrasi Provinsi Jawa Tengah, 2020.

Berdasarkan tabel tersebut dapat diketahui bahwa angka pekerja yang terdampak kebijakan penanganan Covid-19 di Kota Semarang memiliki jumlah tertinggi. Pekerja yang di PHK dan 'di rumahkan' mencapai 15.883 orang pekerja, dengan rincian 7.142 orang kehilangan pekerjaan karena di PHK dan sisanya (8.741 orang) terpaksa 'di rumahkan' oleh perusahaannya karena tidak dapat beroperasi.

Situasi tersebut secara langsung atau tidak langsung merupakan akibat dari penerapan kebijakan PSBB (Pembatasan Sosial Berskala Besar) sebagai upaya Pemerintah untuk menghambat laju penyebaran Covid-19. Hal itu sebagaimana diatur dalam Peraturan Pemerintah (PP) Nomor 21 Tahun 2020 tentang Pembatasan Sosial Berskala Besar Dalam Rangka Percepatan Penanganan Covid-

${ }^{7}$ Disampaikan oleh Menteri Tenaga Kerja, Ida Fauziyah, pada Peluncuran Hasil Analisis Dampak Covid19 terhadap Perluasan Kesempatan Kerja dan Implikasinya, Selasa 24 November 2020.

8 Riska Farasonalia, "Dampak Corona, 24 Ribu Buruh di-PHK", https://semarang.kompas.com/ $\mathrm{read} / 2020 / 04 / 08 / 05252591 /$ dampak-corona-24-ribu-buruh-di-phk-ganjar-silakan- daftar-kartu-prakerja, diakses pada 23 April 2020. 
19 yang kemudian diatur lebih lanjut dalam Peraturan Menteri Kesehatan Nomor 9 Tahun 2020 tentang Pedoman Pembatasan Sosial Berskala Besar dalam Rangka Percepatan Penanganan Covid-19.

Pemerintah Kota Semarang menindaklanjuti kebijakan tersebut dengan mengeluarkan Peraturan Walikota (Perwal) Nomor 28 Tahun 2020 tentang Pedoman Pelaksanaan Pembatasan Kegiatan Masyarakat Dalam Rangka Percepatan Penanganan Covid-19 di Kota Semarang. Perwal tersebut secara garis besar mengatur tentang berbagai pembatasan kegiatan di luar rumah, seperti penghentian kegiatan di sekolah dan institusi pendidikan lainnya, pembatasan kegiatan di tempat kerja, tempat ibadah dan tempat umum; serta pembatasan kegiatan sosial budaya dan pengerahan orang melalui moda transportasi.

Kebijakan yang membatasi kegiatan masyarakat ini, di satu sisi bertujuan untuk menghambat penyebaran virus Covid-19, yang berarti Pemerintah ingin memenuhi kewajibannya untuk melindungi hak atas kesehatan dan keselamatan masyarakatnya. Namun di sisi lain kebijakan tersebut juga berdampak sangat signifikan pada perekonomian masyarakat yang berimbas pada sektor ketenagakerjaan. Banyak perusahaan yang tidak mampu mempertahankan pekerjanya, sehingga terpaksa harus merumahkannya atau bahkan melakukan PHK. Artinya bahwa para pekerja yang terdampak Covid-19 ini kehilangan haknya atas pekerjaan, sehingga berpotensi tidak memperoleh penghasilan dan penghidupan yang layak.

Negara, dalam hal ini Pemerintah, memiliki kewajiban dan tanggung jawab untuk menghormati (to respect), memenuhi (to fulfil) dan melindungi (to protect) HAM bagi warganya. ${ }^{9}$ Hal ini diatur dalam Pasal 28 I ayat (4) UUD NRI 1945, Pasal 8 jo Pasal 71 UU Nomor 39 tentang Hak Asasi Manusia (HAM) yang menegaskan bahwa Negara wajib dan bertanggung jawab untuk menghormati, melindungi, menegakkan dan memajukan HAM, baik yang diatur dalam hukum nasional maupun Hukum Internasional yang sudah diterima Negara Republik Indonesia.

Negara dalam melaksanakan kewajibannya tersebut harus mengambil semua langkah implementatif yang diperlukan, yaitu hukum, politik, ekonomi, sosial, budaya, pertahanan, keamanan negara dan bidang lainnya (Pasal 72 UU

\footnotetext{
${ }^{9}$ Rahayu, Hukum Hak Asasi Manusia, Edisi Revisi, Badan Penerbit Undip, Semarang, 2015, hlm. 59.
} 
No. 39/1999 tentang HAM). Namun perlu dipahami bahwa kewajiban negara ini tidak semata-mata didasarkan pada kewajiban atas suatu perundang-undangan, namun juga didasarkan pada moralitas untuk menjunjung tinggi harkat dan martabat manusia. Kewajiban negara ini tidak dapat diingkari, karena merupakan bagian dari kewajiban negara untuk melindungi kepentingan umat manusia (obligation erga omnes). ${ }^{10}$

Terkait dengan hal tersebut di atas, maka merupakan hal yang menarik untuk mengkaji lebih lanjut tentang pemenuhan kewajiban negara terhadap pekerja terdampak Covid-19 di Kota Semarang. Hal ini mengingat bahwa angka pekerja yang terdampak kebijakan penanganan Covid-19 di Kota Semarang memiliki jumlah tertinggi diantara beberapa daerah di Provinsi Jawa Tengah. Mencermati hal tersebut maka diperlukan kajian lebih mendalam sehubungan dengan implikasinya terhadap status ketenagakerjaan para pekerja serta konteks pemenuhan kewajiban negara cq. Pemerintah Daerah terhadap para perkeja yang terdampak kebijakan penanganan Covid-19.

\section{Rumusan Masalah}

Berdasarkan uraian permasalahan di atas, maka penelitian ini fokus mengkaji 2 rumusan masalah, yaitu: pertama, bagaimana dampak kebijakan penanganan Covid-19 terhadap status ketenagakerjaan para pekerja di Kota Semarang? Kedua, bagaimana pemenuhan kewajiban negara melalui Pemerintah Kota Semarang terhadap pekerja terdampak kebijakan penanganan Covid-19?

\section{Tujuan Penelitian}

Penelitian ini bertujuan yakni, pertama, mengidentifikasi dan menganalisis lebih lanjut dampak kebijakan penanganan pandemi Covid-19 terhadap status ketenagakerjaan para pekerja di Kota Semarang. Kedua, mengidentifikasi dan menganalisis upaya yang dilakukan oleh Pemerintah Kota Semarang dalam melaksanakan kewajibannya memenuhi hak para pekerja.

${ }^{10}$ Ibid., hlm. 61. 


\section{Metode Penelitian}

Penelitian ini ditulis secara kualitatif dengan menggunakan pendekatan doktrinal, yaitu pendekatan yang lebih menitikberatkan pada penggunaan konsep, asas dan norma hukum terkait dengan isu yang diteliti, yaitu aspek ketenagakerjaan dan aspek hak asasi manusia. Penelitian dilakukan di Kota Semarang, karena dari data yang diperoleh ternyata angka pekerja yang terdampak Covid-19 di Kota Semarang memiliki jumlah tertinggi di Provinsi Jawa Tengah.

Data yang digunakan adalah data sekunder yang meliputi bahan hukum primer berupa berbagai peraturan dan kebijakan sektor terkait; bahan hukum sekunder berupa rujukan ilmiah dari berbagai artikel maupun buku; serta berbagai data dan informasi yang dapat diakses dari berbagai media, baik cetak maupun online dengan tetap memerhatikan akurasinya, maupun data yang diperoleh dari berbagai pihak terkait, seperti Kantor Dinas Tenaga Kerja dan Transmigrasi Provinsi Jawa Tengah maupun Dinas Tenaga Kerja Kota Semarang, Kantor Dinas Sosial Kota Semarang, Kantor Pemerintah Kota Semarang, dsb.

Seluruh data yang terkumpul kemudian diseleksi dan disajikan secara sistematis, baik dalam bentuk narasi (deskriptif) maupun tabel untuk kemudian dianalisis decara kualitatif untuk menjawab permasalahan dalam bentuk artikel ilmiah ini.

\section{Hasil Penelitian dan Pembahasan}

\section{Dampak Pandemi Covid-19 terhadap Status Ketenagakerjaan Para Pekerja di Kota Semarang}

Pandemi Covid-19 telah mengakibatkan 2 status baru bagi sebagian pekerja di Kota Semarang, yaitu pemutusan hubungan kerja (PHK) dan 'di rumahkan'. Terdapat sekitar 89 perusahaan dari 4.083 perusahaan yang terdaftar pada Dinas Tenaga Kerja Kota Semarang pada Desember 2020 yang terdampak dengan 7.142 orang terkena PHK dan 8.741 orang 'di rumahkan' sebagaimana dapat dilihat dalam tabel di bawah ini: 
Tabel 2

Jumlah Perusahaan dan Pekerja Terdampak Covid-19 di Kota Semarang

\begin{tabular}{lcc}
\multicolumn{1}{c}{ Status } & $\begin{array}{c}\text { Jumlah } \\
\text { Perusahaan }\end{array}$ & $\begin{array}{c}\text { Jumlah } \\
\text { Pekerja }\end{array}$ \\
\hline Terdaftar pada Dinas Tenaga Kerja Kota Semarang & 4.083 & 230.099 \\
Terdampak Covid-19 & 89 & 15.883 \\
PHK & - & 7.142 \\
'Di rumahkan' & - & 8.741 \\
\hline
\end{tabular}

Sumber : Diolah dari Data Kantor Dinas Tenaga Kerja Kota Semarang, Desember 2020.

Jenis usaha yang paling terkena dampak adalah sektor industri (garmen, manufaktur, meubel/kayu/furniture, plastik, logam, keramik, dll); sektor jasa (perekrutan tenaga kerja, transportasi, perhotelan, asuransi, percetakan, hiburan, restoran dan makanan, kontraktor, kesehatan dan farmasi, dll); serta usaha mandiri (UMK dan UMKM). Secara rinci data tersebut dapat dilihat pada tabel berikut ini:

Tabel 3

Jenis Usaha dan Jumlah Pekerja Terdampak Covid-19 di Kota Semarang Tahun 2020

\begin{tabular}{llcc}
\hline No & \multicolumn{1}{c}{ Jenis Usaha } & $\begin{array}{c}\text { Pekerja yang di } \\
\text { PHK (Orang) }\end{array}$ & $\begin{array}{c}\text { Pekerja yang di } \\
\text { rumahkan (Orang) }\end{array}$ \\
\hline A. & Sektor Industri & 5.218 & 2.015 \\
1. & Garmen & 3.593 & 1.341 \\
2. & Mebel & 227 & 370 \\
3. & Logam & 368 & 59 \\
4. & Kayu & 70 & - \\
5. & Keramik & - & 154 \\
6. & Manufaktur & 424 & 36 \\
7. & Sarung tangan & 45 & - \\
8. & Karet dan Ban & 40 & 5 \\
9. & Plastik & 451 & 50 \\
B. & Sektor Jasa & 457 & 3.434 \\
1. & Perekrutan Tenaga Kerja & 219 & 1.757 \\
2. & Perhotelan & 50 & 758 \\
3. & Restoran dan Makanan & 15 & 289 \\
4. & Kesehatan dan Farmasi & 43 & 111 \\
5. & Percetakan & 58 & 70 \\
6. & Hiburan / Entertainment & - & 217 \\
7. & Kontraktor & - & 152 \\
\hline
\end{tabular}




\begin{tabular}{rlcc}
\hline 8. & Manajemen Parkir & 50 & - \\
9. & Asuransi & 2 & - \\
10. & Transportasi & 13 & 80 \\
11. & Distributor Migas \& Lainnya & 7 & - \\
\hline C. & Usaha Mandiri & 1.467 & 3.292 \\
\hline & & $\mathbf{7 . 1 4 2}$ & $\mathbf{8 . 7 4 1}$ \\
\hline
\end{tabular}

Sumber : Diolah dari Data Dinas Tenaga Kerja Kota Semarang, Desember 2020.

Data tersebut menunjukkan bahwa di Kota Semarang, sektor industri menjadi sektor yang pekerjanya paling banyak terdampak kebijakan penanganan Covid-19 (7.233 orang), diikuti oleh usaha mandiri (4.759 orang) dan sektor jasa (3.891 orang).

Terkait dengan pekerja yang di PHK, sebagian perusahaan menggunakan alasan pandemi Covid-19 sebagai 'force majeure' (keadaan memaksa) atau 'overmacht', yaitu keadaan dimana seseorang tidak dapat melaksanakan prestasinya karena ada peristiwa yang terjadi diluar kemampuan dirinya, seperti misalnya bencana alam. Keadaan memaksa tersebut harus berada di luar kekuasaan pihak yang mestinya memenuhi kewajibannya, serta tidak dapat diketahui pada saat perjanjian dibuat. ${ }^{11}$

Force majeure diatur dalam Pasal 1244 dan Pasal 1245 KUH Perdata (tidak dapat melaksanakan prestasi karena suatu keadaan yang memaksa); serta Pasal 1444 dan Pasal 1445 KUH Perdata terkait hilang, rusak atau musnah barang yang diperjanjikan karena keadaan yang memaksa. Penggunaan 'force majeure' sebagai alasan untuk melakukan pemutusan hubungan kerja (PHK) sebenarnya sudah diatur dalam Pasal 164 ayat (1) UU Nomor 13 Tahun 2003 tentang Ketenagakerjaan:12

Pengusaha dapat melakukan pemutusan hubungan kerja terhadap pekerja/buruh karena perusahaan tutup yang disebabkan perusahaan mengalami kerugian secara terus menerus selama 2 (dua) tahun, atau keadaan memaksa (force majeure), dengan ketentuan pekerja/buruh berhak atas uang pesangon sebesar I (satu) kali ketentuan Pasal 156 ayat (2) uang penghargaan masa kerja sebesar I (satu) kali ketentuan Pasal 156 ayat (3) dan uang penggantian hak sesuai ketentuan Pasal 156 ayat (4).

\footnotetext{
${ }^{11}$ Subekti, Pokok Pokok Hukum Perdata, PT Intermasa, Jakarta, 2011.

12 Pasal ini di dalam UU Nomor 11 Tahun 2020 tentang Cipta Kerja dihapus, dan mengenai 'force majeure' sebagai alasan PHK lebih lanjut diatur dalam Pasal 154 A ayat (1) huruf d.
} 
Pasal 61 ayat (1) huruf d UU Ketenagakerjaan mengatur bahwa perjanjian kerja berakhir bila '...ada keadaan atau kejadian tertentu yang dicantumkan dalam perjanjian kerja, peraturan perusahaan, atau perjanjian kerja bersama yang dapat menyebabkan berakhirnya hubungan kerja...'. Ada pun yang dimaksud dengan 'keadaan atau kejadian tertentu', menurut penjelasan Pasal 61 ayat (1) huruf d adalah '...keadaan atau kejadian tertentu seperti bencana alam, kerusuhan sosial dan gangguan keamanan...'. ${ }^{13}$

Bagi kelompok yang tidak sepakat menggunakan pandemi Covid-19 sebagai alasan 'keadaan memaksa' (force majeure) untuk melakukan PHK atau merumahkan pekerjanya, biasanya berpegang teguh pada alasan bahwa pandemi Covid-19 bukan merupakan bencana alam. Selain itu alasan kerugian yang dialami perusahaan juga belum memenuhi jangka waktu yang ditentukan, yaitu 2 (dua) tahun secara terus menerus sehingga perusahaan tersebut tutup, karena pandemi Covid-19 belum genap mencapai jangka waktu tersebut. ${ }^{14}$ Menurut Abdussalam, pada prinsipnya perusahaan tidak dapat melakukan pemutusan hubungan kerja dengan alasan apapun, manakala pekerja tersebut tetap mentaati segala peraturan yang ada pada perusahaan serta mematuhi segala kewajiban yang termuat dalam perjanjian kerja antara pekerja dan pemberi kerja. ${ }^{15}$

Merujuk pada keadaan pandemi saat ini, pada dasarnya perusahaan memiliki beberapa pilihan langkah yang dapat ditempuh terlebih dahulu sebelum memutuskan untuk melakukan tindakan pemutusan hubungan kerja. Mengacu kepada Surat Edaran Menteri Ketenagakerjaan dan Transmigrasi Nomor 907/Men/PHI-PPHI/X/2004 tentang Pencegahan Pemutusan Hubungan Kerja, terdapat beberapa langkah sebagai berikut:

1. Mengurangi hak upah serta fasilitas pekerja tingkat pimpinan perusahaan;

2. Mengurangi jumlah giliran dalam perusahaan;

3. Melakukan pembatasan atau menghapuskan sementara kerja lembur;

${ }^{13}$ Kajian ini masih menggunakan UU Nomor 13 Tahun 2003 tentang Ketenagakerjaan sebagai landasan hukum utama, karena kasus-kasus yang muncul dalam penelitian ini terjadi sebelum UU Cipta Kerja disahkan pada tanggal 2 November 2020. Bahkan Peraturan Pemerintah yang mengatur lebih lanjut ketentuan-ketentuan dalam UU tersebut baru muncul pada awal Februari 2021, yaitu Peraturan Pemerintah (PP) Nomor 34 tentang Penggunaan Tenaga Kerja Asing, PP Nomor 35 tentang Perjanjian Kerja Waktu Tertentu, Alih Daya, Waktu Kerja dan Waktu Istirahat, dan Pemutusan Hubungan Kerja; serta PP Nomor 36 tentang Pengupahan.

${ }^{14}$ Imas Novita Juaningsih, "Analisis Kebijakan PHK Bagi Para Pekerja pada Masa Pandemi Covid-19”, Jurnal Hukum Adalah: Buletin Hukum dan Keadilan, Vol. 4 Nomor 1, Tahun 2020, hlm. 190.

15 Abdussalam, Hukum Ketenagakerjaan, Restu Agung, Jakarta, 2009, hlm. 109. 
4. Melakukan pengurangan terhadap jam kerja dan hari kerja;

5. Merumahkan pekerja secara bergiliran untuk sementara waktu;

6. Tidak memberikan perpanjangan kontrak bagi para pekerja kontrak yang telah habis masa kontrak kerjanya; dan

7. Segera memberikan pensiun bagi para pekerja yang telah memenuhi syarat.

Surat Edaran tersebut dapat dijadikan dasar kebijakan bagi perusahaanperusahaan yang terdampak kebijakan pandemi Covid-19 untuk tidak serta merta menjadikan alasan force majeur untuk melakukan efisiensi sumber daya manusia dengan melakukan PHK atau merumahkan pekerjanya. Namun di sisi lain, berdasarkan fakta yang ada, semakin berlarutnya pandemi Covid-19 yang belum jelas kapan berakhir ini, telah berdampak sangat luar biasa, tidak hanya sebagai krisis kesehatan namun juga krisis ekonomi yang memukul dunia usaha dengan keras termasuk para pekerjanya. ${ }^{16}$ Banyak perusahaan yang kemudian menggunakan alasan 'keadaan memaksa' ini untuk melakukan PHK atau merumahkan pekerjanya.

Alasan bagi kelompok yang sepakat bahwa pandemi Covid-19 dapat dikategorikan sebagai 'keadaan memaksa', karena menganggap bahwa ketentuan hukum positif yang saat ini ada di Indonesia masih sangat bersifat umum dan belum mengatur 'pandemi' sebagai salah satu alasan 'force majeure'. Hal ini berbeda dengan International Chambers of Commerce (ICC) yang tanggap menyikapi situasi pandemi Covid-19 ini dengan memperbarui pengertian 'force majeure' pada bulan Maret 2020 menjadi sebagai berikut: ${ }^{17}$

In order for an event to be considered a force majeure under the ICC Force Majeure Clause 2020, all of the following conditions must exist concurrently:

1. the impediment is beyond reasonable control;

2. the impediment could not have been reasonably foreseen at the time of the conclusion of the contract; and

3. the effects of the impediment could not have been reasonably avoided or overcome by the Affected Party (defined as the party affected by the impediment under the ICC Force Majeure Clause 2020).

\footnotetext{
${ }^{16}$ Nikodemus Maringan, “Tinjauan Yuridis Pemutusan Hubungan Kerja Secara Sepihak oleh Perusahaan Menurut Undang-Undang Nomor 13 Tahun 2003 tentang Ketenagakerjaan”, Jurnal Ilmu Hukum Legal Opinion, Volume 3 Nomor 2, Tahun 2015, hlm. 2.

${ }^{17}$ International Chambers of Commerce Force Majeure and Hardship Clauses March 2020, Act No. 3 Presumed Force Majeure Event.
} 
Selanjutnya ICC mengualifikasikan beberapa keadaan yang dapat disebut sebagai 'force majeure', yaitu: 18

a. war (whether declared or not), hostilities, invasion, act of foreign enemies, extensive military mobilisation;

$b$. civil war, riot, rebellion and revolution, military or usurped power, insurrection, act of terrorism, sabotage or piracy;

c. currency and trade restriction, embargo, sanction;

d. act of authority whether lawful or unlawful, compliance with any law or governmental order, expropriation, seizure of works, requistion, nationalisation;

e. plague, epidemic, natural disaster or extreme natural event;

f. explosion, fire, destruction of equipment, prolonged break-down of transport, telecommunication, information system or energy;

g. general labour disturbance such as boycott, strike and lock-out, go slow, occupation of factories and premises.

Berdasarkan ketentuan di atas maka suatu keadaan terjadi '...plague...' (wabah) dapat menjadi alasan 'force majeure'. Apalagi pandemi yang sebaran wabah penyakit tersebut sangat meluas dan bersifat global ke hampir seluruh penjuru dunia. Penggunaan pandemi Covid-19 sebagai alasan 'force majeure' oleh para pengusaha di Indonesia untuk melakukan PHK pekerjanya sebenarnya tidak bertentangan dengan hukum nasional yang berlaku, karena sesuai dengan Keppres Nomor 12 Tahun 2020 penyebaran Covid-19 ditetapkan sebagai bencana non-alam yang merupakan bencana nasional. Pandemi Covid-19 yang terjadi ini dapat dikategorikan sebagai force majeure temporer, sehingga perusahaan dianggap tidak mampu menjalankan fungsinya secara penuh sebagai pemberi kerja untuk sementara waktu dikarenakan adanya kondisi mendesak yang terjadi hingga semuanya kembali kepada kondisi normal.19

\section{Pemenuhan Kewajiban Negara oleh Pemerintah Kota Semarang terhadap Pekerja Terdampak Kebijakan Penanganan Covid-19}

Pasal 27 ayat (2) Undang-Undang Dasar Negara Republik Indonesia Tahun 1945 menegaskan bahwa setiap warga negara Indonesia berhak atas pekerjaan dan penghidupan yang layak. Pengakuan hak ini menimbulkan kewajiban bagi negara untuk menghormati (to respect), memenuhi (to fulfill) dan melindungi (to

\footnotetext{
18 Ibid.

19 Mariam Darus Badrulzaman, Hukum Perikatan dalam KUH Perdata Buku Ketiga (Yurisprudensi, Doketrin, Suatu Penjelasan), Citra Aditya Bakti, Bandung, 2015, hlm. 35-36.
} 
protect) hak tersebut. ${ }^{20}$ Kewajiban untuk menghormati (obligation to respect) dimaksudkan agar negara menahan diri untuk tidak melakukan intervensi kecuali atas hukum yang sah. Hak atas pekerjaan yang layak yang dimiliki setiap warga negara, melahirkan kewajiban negara untuk tidak secara sewenangwenang menyingkirkan siapa pun dari pekerjaan.

Kewajiban untuk memenuhi (obligation to fulfill) adalah kewajiban negara untuk mengambil langkah-langkah yang diperlukan untuk menjamin pelaksanaan HAM seluas mungkin. Pemenuhan hak atas pekerjaan mewajibkan negara untuk mengambil semua kebijakan dan membangun suatu mekanisme yang diperlukan agar semua orang memiliki akses terhadap pasar kerja. Sedang kewajiban untuk melindungi (obligation to protect), tidak hanya dari pelanggaran yang dilakukan negara, namun juga dari pelanggaran atau tindakan yang dilakukan oleh pihak lain yang akan mengganggu upaya pelindungan tersebut. Pemerintah Kota Semarang harus mengambil langkah-langkah yang diperlukan, baik di bidang legislatif, administratif maupun praksis untuk menciptakan semua kondisi yang dibutuhkan dalam berbagai bidang, baik sosial, ekonomi, politik maupun jaminan hukum yang diperlukan agar para pekerja yang terdampak ini tetap dapat memperoleh haknya sebagaimana mestinya.

Pelindungan terhadap pekerja, yang merupakan salah satu isu yang sangat krusial, dimaksudkan untuk menjamin hak-hak dasar pekerja dan menjamin kesamaan kesempatan serta perlakuan tanpa diskriminasi atas apapun untuk mewujudkan kesejahteraan pekerja dan keluarganya dengan tetap memerhatikan perkembangan kemajuan dunia usaha dan kepentingan pengusaha. ${ }^{21}$ Jaminan pelindungan hukum bagi para pekerja merupakan hal yang sangat penting untuk menghindari kemungkinan terjadinya eksploitasi terhadap pekerja.

Mulyani berpendapat bahwa masalah ketenagakerjaan pada dasarnya merupakan pemasalahan yang kompleks karena berdiri diantara ranah hukum privat dan hukum publik secara bersamaan yang membuat negara menjadi perlu

${ }^{20}$ Rahayu, Op. Cit., hlm. 59.

${ }^{21}$ Barzah Latupono, "Perlindungan Hukum dan Hak Asasi Manusia Terhadap Pekerja Kontrak di Kota Ambon”, Jurnal Hukum S ASI, Volume 17, Nomor 3, Juli 2011, hlm. 59. 
untuk menengahi hal tersebut. ${ }^{22}$ Negara kemudian hadir dengan mengatur hak dan kewajiban bagi pekerja dalam Undang-Undang Nomor 13 Tahun 2003 tentang Ketenagakerjaan. Undang-Undang ini kemudian mengalami beberapa perubahan (revisi) melalui Undang-Undang Nomor 11 Tahun 2020 tentang Cipta Kerja yang disahkan pada 2 November 2020 yang diharapkan dapat memudahkan iklim investasi di Indonesia yang kemudian juga akan meningkatkan jumlah lapangan kerja. ${ }^{23}$

Terkait dengan tindakan perusahaan yang melakukan pemutusan hubungan kerja (PHK) atau merumahkan pekerjanya karena terdampak Covid-19, maka sehubungan dengan hak-hak pekerja tersebut dapat disampaikan sebagai berikut:

\section{Hak-hak Pekerja dengan Status PHK}

Ketentuan mengenai hak-hak yang diperoleh oleh pekerja karena di PHK, dalam UU Nomor 13 Tahun 2003 tentang Ketenagakerjaan diatur dalam Pasal 156, sedang dalam UU Nomor 11 Tahun 2020 tentang Cipta Kerja diatur dalam Pasal 154 A dan lebih lanjut diatur dalam Peraturan Pemerintah Nomor: 35 Tahun 2021 tentang Perjanjian Kerja Waktu Tertentu, Alih Daya, Waktu Kerja dan Waktu Istirahat, dan Pemutusan Hubungan Kerja (PHK).

Terkait dengan tindakan perusahaan yang melakukan pemutusan hubungan kerja (PHK) sebagai akibat terdampak oleh kebijakan penanganan Covid-19 yang terjadi pada kurun waktu 2020, bila kasusnya terjadi sebelum 2 November 2020, maka dasar hukum utama yang digunakan adalah masih UU Nomor 13 Tahun 2003 tentang Ketenagakerjaan. Sedangkan untuk kasus-kasus yang terjadi setelah UU Cipta Kerja disahkan, maka para pihak (pengusaha dan pekerja) dapat menggunakan dasar hukum UU baru tersebut dengan merujuk pada PP Nomor 35 tahun 2021 sebagai peraturan pelaksananya. Terdapat beberapa perbedaan hak yang diperoleh pekerja yang di PHK, sebagaimana dapat dilihat dalam tabel berikut ini: ${ }^{24}$

22 Mulyani Djakaria, "Perlindungan Hukum Bagi Pekerja Wanita Untuk Memperoleh Hak-Hak Pekerja Dikaitkan dengan Kesehatan Reproduksi”, Jurnal Hukum Bina Mulia, Volume 3, Nomor 1, September 2018, hlm. 21.

${ }^{23}$ Julkifli Sinuhaji, Jokowi: Tujuan UU Ciptakerja untuk Sediakan Lapangan Kerja Sebanyak banyaknya. https://www.pikiran-rakyat.com/nasional/pr-01816682/jokowi-tujuan-uu-cipta-kerja-untuk-sediakan-lapangankerja-sebanyak-banyaknya, diakses pada 7 Februari 2021.

24 https://siplawfirm.id/catatan-penting-sektor-ketenagakerjaan-setelah-disahkannya-pp-nomor-35tahun-2021/ - diakses pada 24 Mei 2021 


\section{Tabel 4}

Perbandingan Hak Pekerja yang Mengalami PHK

Berdasarkan UU Nomor 13 Tahun 2003 tentang Ketenagakerjaan dengan PP Nomor 35 Tahun 2021

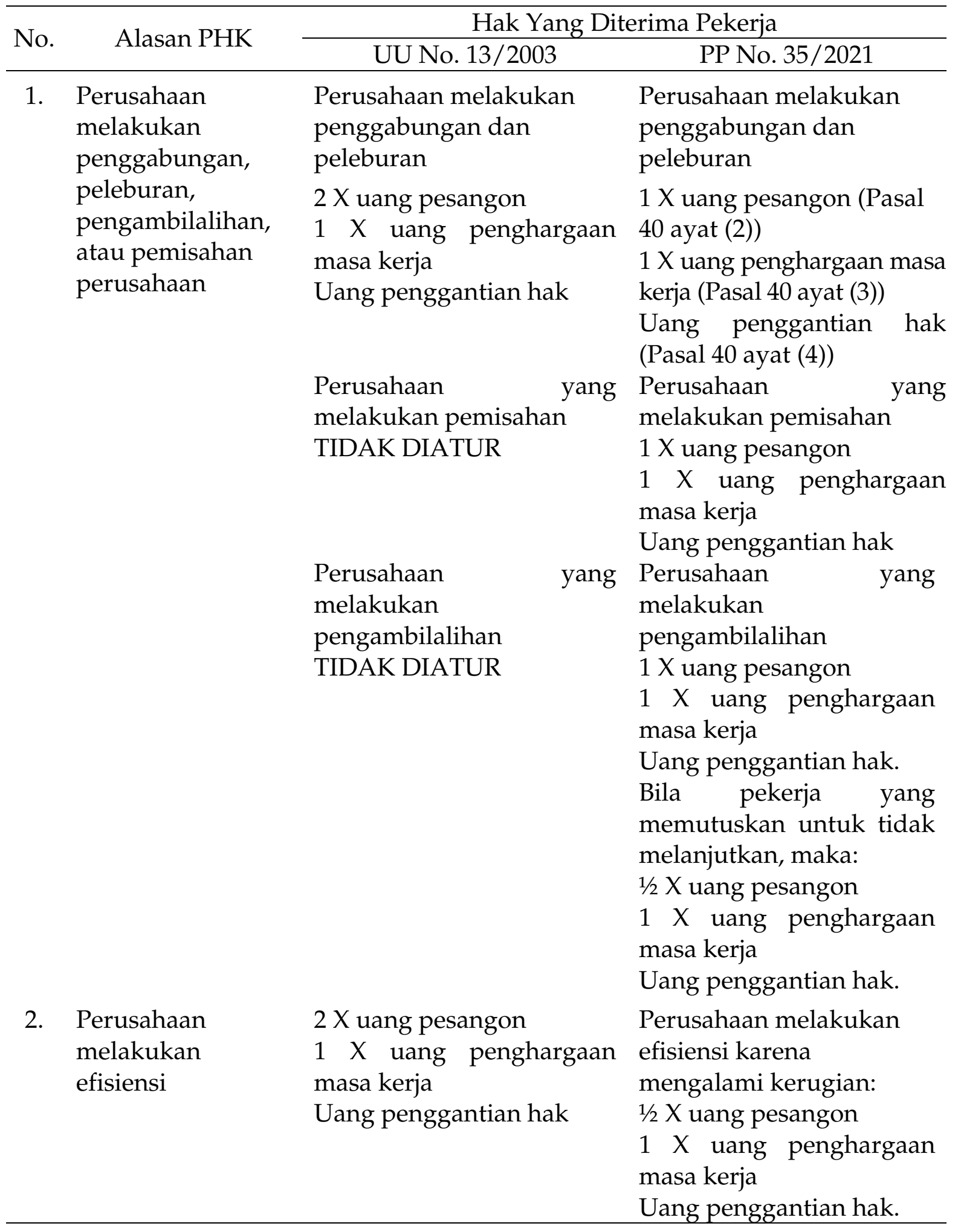


3. Perusahaan tutup karena mengalami kerugian selama 2 (dua) tahun berturut-turut

Dengan syarat harus dibuktikan dengan laporan keuangan: $1 \mathrm{X}$ uang pesangon $1 \mathrm{X}$ uang penghargaan masa kerja

4. Perusahaan tutup karena force majeure

5. Perusahaan dalam keadaan penundaan kewajiban pembayaran utang (PKPU)

6. Perusahaan pailit

7. Permohonan PHK yang diajukan pekerja karena pengusaha melakukan tindak criminal yang merugikan pekerja

$1 \mathrm{X}$ uang pesangon masa kerja

Uang penggantian hak.

TIDAK DIATUR masa kerja masa kerja Uang penggantian hak.

Perusahaan melakukan efisiensi untuk mencegah perusahaan mengalami kerugian:

$1 \mathrm{X}$ uang pesangon

$1 \mathrm{X}$ uang penghargaan masa kerja

Uang penggantian hak.

$1 / 2 X$ uang pesangon

$1 \mathrm{X}$ uang penghargaan masa kerja

Uang penggantian hak.

$1 \mathrm{X}$ uang penghargaan

$1 / 2 X$ uang pesangon

$1 \mathrm{X}$ uang penghargaan masa kerja

Uang penggantian hak.

PKPU karena kerugian perusahaan:

$1 / 2 X$ uang pesangon

$1 \mathrm{X}$ uang penghargaan

masa kerja

Uang penggantian hak.

PKPU bukan disebabkan oleh kerugian perusahaan:

$1 \mathrm{X}$ uang pesangon

$1 \mathrm{X}$ uang penghargaan masa kerja

Uang penggantian hak.

$1 \mathrm{X}$ uang pesangon $\quad 1 / 2 \mathrm{X}$ uang pesangon

$1 \mathrm{X}$ uang penghargaan $1 \mathrm{X}$ uang penghargaan masa kerja Uang penggantian hak. Uang penggantian hak.

$2 \mathrm{X}$ uang pesangon $\quad 1 \mathrm{X}$ uang pesangon

$2 \mathrm{X}$ uang penghargaan $1 \mathrm{X}$ uang penghargaan masa kerja Uang penggantian hak. Uang penggantian hak. 


\begin{tabular}{|c|c|c|c|}
\hline 8. & $\begin{array}{l}\text { Putusan Lembaga } \\
\text { PHI yang } \\
\text { menyatakan } \\
\text { pengusaha tidak } \\
\text { melakukan } \\
\text { perbuatan yang } \\
\text { merugikan pekerja }\end{array}$ & $\begin{array}{l}\text { Tidak berhak } \\
\text { mendapatkan pembayaran } \\
\text { atas upah pesangon, uang } \\
\text { penghargaan masa kerja, } \\
\text { maupun uang } \\
\text { penggantian hak. }\end{array}$ & $\begin{array}{l}\text { Uang penggantian hak } \\
\text { dan uang pisah. }\end{array}$ \\
\hline 9. & $\begin{array}{l}\text { Pekerja } \\
\text { mengundurkan } \\
\text { diri atas kemauan } \\
\text { sendiri }\end{array}$ & $\begin{array}{l}\text { Uang penggantian hak } \\
\text { dan uang pisah. }\end{array}$ & $\begin{array}{l}\text { Uang penggantian hak } \\
\text { dan uang pisah. }\end{array}$ \\
\hline 10. & $\begin{array}{l}\text { Pekerja mangkir } 5 \\
\text { (lima) hari } \\
\text { berturut-turut } \\
\text { tanpa keterangan } \\
\text { tertulis dilengkapi } \\
\text { bukti yang sah dan } \\
\text { telah dipanggil } \\
\text { oleh pengusaha } 2 \\
\text { (dua) kali secara } \\
\text { patut. }\end{array}$ & $\begin{array}{l}\text { Uang penggantian hak } \\
\text { dan uang pisah. }\end{array}$ & $\begin{array}{l}\text { Uang penggantian hak } \\
\text { dan uang pisah. }\end{array}$ \\
\hline 11. & $\begin{array}{l}\text { Pekerja melanggar } \\
\text { ketentuan } \\
\text { Perjanjian Kerja, } \\
\text { Peraturan } \\
\text { Perusahaan, atau } \\
\text { Perjanjian Kerja } \\
\text { Bersama setelah } \\
\text { diberikan } 3 \text { (tiga) } \\
\text { kali surat } \\
\text { peringatan }\end{array}$ & $\begin{array}{l}1 \mathrm{X} \text { uang pesangon } \\
1 \mathrm{X} \text { uang penghargaan } \\
\text { masa kerja } \\
\text { Uang penggantian hak. }\end{array}$ & $\begin{array}{l}1 / 2 X \text { uang pesangon } \\
1 X \text { uang penghargaan } \\
\text { masa kerja } \\
\text { Uang penggantian hak. }\end{array}$ \\
\hline 12. & $\begin{array}{l}\text { Pekerja tidak } \\
\text { dapat melakukan } \\
\text { pekerjaan selama } 6 \\
\text { (enam) bulan } \\
\text { karena diduga } \\
\text { telah melakukan } \\
\text { tindak pidana. }\end{array}$ & $\begin{array}{l}1 \mathrm{X} \text { uang pesangon } \\
\text { Uang penggantian hak. }\end{array}$ & $\begin{array}{l}\text { Tindak pidana yang } \\
\text { mengakibatkan kerugian } \\
\text { bagi perusahaan: } \\
\text { Uang penggantian hak } \\
\text { dan uang pisah } \\
\text { Tindak pidana yang tidak } \\
\text { mengakibatkan kerugian } \\
\text { bagi perusahaan: } \\
1 \text { X uang penghargaan } \\
\text { masa kerja dan uang } \\
\text { penggantian hak. }\end{array}$ \\
\hline
\end{tabular}




\begin{tabular}{|c|c|c|c|}
\hline \multirow[t]{3}{*}{13.} & Pekerja sakit & $2 X$ uang pesangon & $2 X$ uang pesangon \\
\hline & $\begin{array}{l}\text { berkepanjangan } \\
\text { dan tidak }\end{array}$ & $\begin{array}{l}1 \mathrm{X} \text { uang penghargaan } \\
\text { masa kerja }\end{array}$ & $\begin{array}{l}1 \mathrm{X} \text { uang penghargaan } \\
\text { masa kerja }\end{array}$ \\
\hline & $\begin{array}{l}\text { mengerjakan } \\
\text { pekerjaannya } \\
\text { selama } 12 \text { (dua } \\
\text { belas) bulan }\end{array}$ & Uang penggantian hak. & Uang penggantian hak. \\
\hline \multirow[t]{3}{*}{14} & Pekerja pensiun & $2 \mathrm{X}$ uang pesangon & $1,75 X$ uang pesangon \\
\hline & & $\begin{array}{l}1 \mathrm{X} \text { uang penghargaan } \\
\text { masa kerja }\end{array}$ & $\begin{array}{l}1 \text { X uang penghargaan } \\
\text { masa kerja }\end{array}$ \\
\hline & & Uang penggantian hak. & Uang penggantian hak. \\
\hline \multirow[t]{3}{*}{15.} & Pekerja meninggal & $2 X$ uang pesangon & $2 X$ uang pesangon \\
\hline & dunia & $\begin{array}{l}1 \mathrm{X} \text { uang penghargaan } \\
\text { masa kerja }\end{array}$ & $\begin{array}{l}1 \text { X uang penghargaan } \\
\text { masa kerja }\end{array}$ \\
\hline & & Uang penggantian hak. & Uang penggantian hak. \\
\hline
\end{tabular}

\section{Hak-hak Pekerja dengan Status 'Di Rumahkan' Sementara}

Selain PHK, keputusan untuk merumahkan para pekerja tetap maupun pekerja kontrak akibat dampak pandemi Covid-19 juga dilakukan oleh banyak perusahaan guna mempertahankan kelangsungan operasional usahanya. Sesuai ketentuan Surat Edaran Menteri Ketenagakerjaan Nomor M/3/HK.04/111/2020 tentang Perlindungan Pekerja/Buruh dan Kelangsungan Usaha dalam Rangka Pencegahan dan Penanggulangan Covid-19 (SE Menaker 3/2020), maka para pekerja yang 'di rumahkan' juga tetap memperoleh hak-haknya sesuai dengan kategorinya sebagai berikut:

a. Bagi pekerja/buruh yang dikategorikan sebagai Orang Dalam Pemantauan (ODP) Covid-19 berdasarkan keterangan dokter sehingga tidak dapat masuk kerja paling lama 14 hari atau sesuai standar Kementerian Kesehatan, maka upahnya dibayarkan secara penuh.

b. Bagi pekerja/buruh yang dikategorikan kasus suspek Covid-19 dan dikarantina/diisolasi menurut keterangan dokter, maka upahnya dibayarkan secara penuh selama menjalani masa karantina/isolasi.

c. Bagi pekerja/buruh yang tidak masuk kerja karena sakit Covid-19 dan dibuktikan dengan keterangan dokter, maka upahnya dibayarkan sesuai peraturan perundang-undangan.

d. Bagi perusahaan yang melakukan pembatasan kegiatan usaha akibat kebijakan pemerintah di daerah masing-masing guna pencegahan dan penanggulangan Covid-19, sehingga menyebabkan sebagian atau seluruh pekerja/buruhnya tidak masuk kerja, dengan mempertimbangkan kelangsungan usaha maka perubahan besaran maupun cara pembayaran 
upah pekerja/buruh dilakukan sesuai dengan kesepakatan antara pengusaha dengan pekerja/buruh.

Berdasar pada Surat Edaran tersebut maka hak-hak pekerja yang 'di rumahkan' oleh perusahaan sebagai akibat kebijakan penanganan Covid-19, ditentukan berdasar kesepakatan antara pengusaha dengan pekerja. Hal ini berlaku, baik untuk pekerja tetap maupun pekerja kontrak. Praktik yang terjadi di Kota Semarang telah sesuai dengan yang tertuang pada surat edaran tersebut yang lebih mengedepankan metode mediasi dalam proses penyelesaian sengketa hubungan industrial. Hal ini selaras dengan hasil temuan peneliti di lapangan yang dilakukan melalui wawancara dengan Sekretaris Dinas Ketenagakerjaan Kota Semarang, Ekwan Priyanto yang menyatakan bahwa:'... persoalan pekerja yang terdampak kebijakan pandemi Covid-19 di Kota Semarang dapat dikomunikasikan dan diselesaikan dengan baik melalui dialog antara pihak perusahaan dengan pekerja. Bilamana menemui kesulitan dalam mencapai kata sepakat, maka pihak perusahaan dan pekerja akan menyelesaikan dengan cara mediasi di Kantor Dinas Tenaga Kerja Kota Semarang. Cara mediasi ini sangat efektif, karena sampai saat ini belum ada persoalan yang dibawa ke ranah pengadilan...' ${ }^{25}$

Terkait dengan pelaksanaan kewajiban negara terhadap pekerja terdampak Covid-19, maka dapat dikatakan bahwa Pemerintah Kota Semarang sudah mengambil tindakan konkrit untuk meminimalisir dampak buruknya. Peraturan Walikota (Perwal) Nomor 28 Tahun 2020 menjadi dasar kebijakan untuk menghambat menyebarnya virus Covid-19. Pasal 7 ayat (2) huruf e Perwal memberikan jaminan perlindungan kepada pekerja yang terdampak Pandemi Covid-19 di Kota Semarang sesuai dengan peraturan perundang-undangan yang berlaku.

Kebijakan ini menjadi bukti komitmen Pemerintah Kota Semarang untuk melindungi hak atas kesehatan masyarakatnya, sekaligus tetap memperhatikan hak masyarakat untuk melakukan aktivitas ekonomi dengan memperhatikan standar kesehatan yang berlaku. Selain itu, Pemerintah Kota Semarang juga

\footnotetext{
25 Hasil Wawancara yang dilakukan dengan Ekwan Priyanto, Sekretaris Dinas Ketenagakerjaan Kota Semarang, pada Senin, 1 Februari 2021.
} 
mengambil langkah taktis lainnya dengan memberikan bantuan-bantuan, baik berupa stimulus, bantuan langsung tunai maupun bantuan sosial lainnya yang diberikan kepada para pekerja terdampak tersebut melalui program yang dikoordinasikan oleh Dinas Sosial Kota Semarang. ${ }^{26}$ Hal tersebut diharapkan dapat meringankan beban pekerja yang terdampak kebijakan pemerintah akibat terjadinya pandemi Covid-19.

\section{Penutup}

Penelitian ini menyimpulkan 2 hal, yaitu: pertama, Pandemi Covid-19 telah berdampak sangat luar biasa di sektor ketenagakerjaan di Kota Semarang. Hal ini dapat dilihat dari jumlah pekerja yang di PHK maupun 'di rumahkan'. Dari 15.883 orang pekerja yang berasal dari 89 perusahaan yang terdampak Covid-19 di kota Semarang, 7.142 orang diantaranya di PHK, dan 8.741 orang 'di rumahkan'. Jenis usaha yang paling terdampak adalah sektor industri (7.233 orang pekerja), diikuti oleh sektor usaha mandiri (4.759 orang pekerja) dan sektor jasa (3.891 orang pekerja).

Kedua, Pemerintah Kota Semarang melalui kebijakannya berusaha memastikan bahwa para pekerja yang terdampak kebijakan penanganan Covid-19, baik yang di PHK maupun 'di rumahkan', tetap dapat memeroleh hak-haknya sesuai dengan ketentuan yang berlaku. Jaminan kebutuhan sehari-hari para pekerja terdampak kebijakan penanganan Covid-19 ini antara lain dipenuhi melalui berbagai program Pemerintah, baik berupa bantuan stimulus maupun bantuan sosial.

\section{Daftar Pustaka}

\section{Buku}

Abdussalam, Hukum Ketenagakerjaan, Restu Agung, Jakarta, 2009.

Badrulzaman, Mariam, Darus, Hukum Perikatan dalam KUH Perdata Buku Ketiga (Yurisprudensi, Doktrin, Suatu Penjelasan, Citra Aditya Bakti, Bandung, 2015.

Rahayu, Hukum Hak Asasi Manusia, Edisi Revisi, Badan Penerbit Undip, Semarang, 2015.

Subekti, Pokok Pokok Hukum Perdata, PT Intermasa, Jakarta, 2011.

${ }^{26}$ Hasil Wawancara yang dilakukan dengan Mutohar, Kepala Dinas Sosial Kota Semarang, pada Jumat 26 Februari 2021. 


\section{Jurnal}

Djakaria, Mulyani, "Perlindungan Hukum Bagi Pekerja Wanita Untuk Memperoleh Hak-Hak Pekerja Dikaitkan dengan Kesehatan Reproduksi", Jurnal Hukum Bina Mulia, Volume 3, Nomor 1, September 2018.

Juaningsih, Imas Novita, “Analisis Kebijakan PHK Bagi Para Pekerja pada Masa Pandemi Covid-19", Jurnal Hukum Adalah: Buletin Hukum dan Keadilan, Vol. 4 Nomor 1, Tahun 2020.

Khalda Fadilah, Andriyanto Adhi Nugroho, "Pemutusan Hubungan Kerja Pada Saat Pandemi Covid-19 Di Indonesia Ditinjau Dari Perspektif Hukum Ketenagakerjaan", JUSTITIA: Jurnal Ilmu Hukum dan Humaniora, Vol. 8 No. 1 Tahun 2021.

Latupono, Barzah, "Perlindungan Hukum dan Hak Asasi Manusia Terhadap Pekerja Kontrak di Kota Ambon", Jurnal Hukum SASI, Volume 17, Nomor 3, Juli 2011.

Maringan, Nikodemus, "Tinjauan Yuridis Pemutusan Hubungan Kerja Secara Sepihak oleh Perusahaan Menurut Undang-Undang Nomor 13 Tahun 2003 tentang Ketenagakerjaan", Jurnal Ilmu Hukum Legal Opinion, Volume 3 Nomor 2, Tahun 2015.

\section{Hasil Penelitian}

Warwick McKibbin and Roshen Fernando, "The Macroeconomics Impact of Covid-19: Seven Scenarios", Centre For Applied Macroeconomics Analysis, Working Paper, February 2020.

\section{Internet}

"Dampak Corona, 24 Ribu Buruh di-PHK", https://semarang.kompas.com/ read/2020/04/08/05252591/dampak-corona-24-ribu-buruh-di-phkganjar-silakan- daftar-kartu-prakerja, diakses pada 23 April 2020.

"Jokowi: Tujuan UU Ciptakerja untuk Sediakan Lapangan Kerja Sebanyak banyaknya", https://www.pikiran-rakyat.com/nasional/pr01816682/jokowi-tujuan-uu-cipta-kerja-untuk-sediakan-lapangan-kerjasebanyak-banyaknya, diakses pada 7 Februari 2021.

"Virus Corona: Gelombang PHK di tengah Pandemi Covid-19 diperkirakan mencapai puncak pada Bulan Juni, Kartu Prakerja Dianggap tak Efektif." https://www.bbc.com/indonesia/indonesia-52218475. Diakses pada hari Sabtu 23 Mei 2020.

"Pertumbuhan Ekonomi RI Minus 5,32 Persen, Apa Dampaknya?" https://www.kompas.com/tren/read/2020/08/05/151948365/pertumb uhan-ekonomi-ri-minus-532-persen-apadampaknya?page=all\#: :text=KOMPAS.com $\% 20 \% 2 \mathrm{D} \% 20$ Pertumbuhan $\%$ 20ekonomi $\% 20$ Indonesia,hingga \%20minus \%204\%2C8\%20persen. Diakses pada hari Sabtu 10 Oktober 2020. 
"Ekonomi Indonesia Triwulan I 2020, Tumbuh 2,97 Persen." https://www.bps.go.id/pressrelease/2020/05/05/1736/ekonomiindonesia-triwulan-i-2020-tumbuh-2-97-persen.html. Diakses pada hari Sabtu 23 Mei 2020.

https://siplawfirm.id/catatan-penting-sektor-ketenagakerjaan-setelah-disahkannyapp-nomor-35-tahun-2021/ - diakses pada tanggal 24 Mei 2021.

\section{Peraturan Perundang-Undangan}

Undang Undang Dasar Negara Republik Indonesia Tahun 1945.

Kitab Undang Undang Hukum Perdata (KUH Per).

Undang Undang Nomor 39 Tahun 1999 tentang Hak Asasi Manusia, Lembaran Negara RI Tahun 1999 Nomor 165, Tambahan Lembaran Negara RI Nomor 3886.

Undang Undang Nomor 13 Tahun 2003 tentang Ketenagakerjaan, Lembaran Negara RI Tahun 2003 Nomor 39, Tambahan Lembaran Negara RI Nomor 4279.

Undang Undang Nomor 11 Tahun 2020 tentang Cipta Kerja, Lembaran Negara RI Tahun 2020 Nomor 245, Tambahan Lembaran Negara RI Nomor 6573.

Peraturan Pemerintah Nomor 35 Tahun 2021 tentang Perjanjian Kerja Waktu Tertentu, Alih Daya, Waktu Kerja dan Waktu Istirahat, dan Pemutusan Hubungan Kerja (PHK).

Keppres Nomor 12 Tahun 2020 tentang Penetapan Bencana Nonalam Penyebaran Corona Virus Disease 2019 (Covid-19) sebagai Bencana Nasional.

Surat Edaran Menteri Ketenagakerjaan dan Transmigrasi Nomor 907/Men/PHIPPHI/X/2004 tentang Pencegahan Pemutusan Hubungan Kerja (PHK).

Surat Edaran Menteri Tenaga Kerja Nomor M/3/HK.04/111/2020 tentang Perlindungan Pekerja/Buruh dan Kelangsungan Usaha dalam Rangka Pencegahan dan Penanggulangan Covid-19.

Peraturan Walikota Semarang Nomor 28 Tahun 2020 tentang Pedoman Pelaksanaan Pembatasan Kegiatan Masyarakat dalam rangka Percepatan Penanganan Covid-19 di Kota Semarang.

\section{Lain-lain}

International Chambers of Commerce Force Majeure and Hardship Clauses March 2020, Act No. 3 Presumed Force Majeure Event. 